\title{
Biological Control of the Raspberry Eriophyoid Mite Phyllocoptes gracilis Using Entomopathogenic Fungi
}

\author{
Camille Minguely ${ }^{1}$, Lindsey Norgrove ${ }^{1}$, Alexander Burren ${ }^{1}$ and Bastien Christ ${ }^{2, *}$ \\ 1 School of Agricultural, Forest and Food Sciences HAFL, Bern University of Applied Sciences, Länggasse 85, \\ 3052 Zollikofen, Switzerland; camilleolivia.minguely@bfh.ch (C.M.); lindsey.norgrove@bfh.ch (L.N.); \\ alexander.burren@bfh.ch (A.B.) \\ 2 Agroscope, Plant Production Systems, Route des Eterpys 18, 1964 Conthey, Switzerland \\ * Correspondence: bastien.christ@agroscope.admin.ch; Tel.: +41-58-466-77-83
}

check for updates

Citation: Minguely, C.; Norgrove, L.; Burren, A.; Christ, B. Biological Control of the Raspberry Eriophyoid Mite Phyllocoptes gracilis Using Entomopathogenic Fungi. Horticulturae 2021, 7, 54. https:// doi.org/10.3390/horticulturae7030054

Academic Editor: Giovanni Bubici

Received: 26 January 2021

Accepted: 15 March 2021

Published: 18 March 2021

Publisher's Note: MDPI stays neutral with regard to jurisdictional claims in published maps and institutional affiliations.

Copyright: (c) 2021 by the authors. Licensee MDPI, Basel, Switzerland. This article is an open access article distributed under the terms and conditions of the Creative Commons Attribution (CC BY) license (https:// creativecommons.org/licenses/by/ $4.0 /)$.

\begin{abstract}
There is an urgent need to develop biological control methods against the eriophyoid mite, Phyllocoptes gracilis, which causes significant losses in organic raspberry production in Europe. The use of entomopathogenic fungi (EF) is a sustainable alternative to conventional chemical pesticides, reducing the risks of pesticide resistance and other negative environmental impacts of agriculture. The objective of this study was to assess the pathogenicity of three strains of EF, two of Beauveria bassiana and one of Metarhizium anisopliae, on P. gracilis under laboratory conditions. Fungal spore suspensions $\left(1 \times 10^{7}\right.$ spores per $\left.\mathrm{mL}\right)$ were sprayed on detached leaves infested with $P$. gracilis. Treated mites were kept under controlled conditions $\left(25 \pm 3{ }^{\circ} \mathrm{C}, 72 \pm 10 \%\right.$ relative humidity and photoperiod of 16:8 (light/dark)) and mite mortality was assessed three, five and seven days after inoculation. At all three measurement points (days after inoculation), the mortality of $P$. gracilis was highest for B. bassiana strain BB 1.1 and M. anisopliae strain MA 10.1. Our data demonstrate that EFs are promising candidates for the development of biological control agents against $P$. gracilis in raspberry crops.
\end{abstract}

Keywords: biological control; Eriophyidae; Phyllocoptes gracilis; entomopathogenic fungi; Beauveria bassiana; Metarhizium anisopliae

\section{Introduction}

In recent years, severe infestations of Phyllocoptes gracilis Nalepa (Acari: Eriophyidae) in Switzerland have had a negative impact on organic raspberry (Rubus idaeus L.) production and resulted in severe economic losses [1]. Due to the small size of $P$. gracilis and its tendency to hide, it is difficult for growers to detect it on crops before the development of symptoms on fruits and leaves [2]. Predatory mites of the Phytoseiidae family are known to feed on eriophyids and to participate in the control of P. gracilis [3]. However, under most raspberry growth conditions, these predatory mites do not seem to prevent a rapid increase in P. gracilis populations. Entomopathogenic fungi (EF) are a more sustainable alternative to chemical pesticides [4]. EF are used in classical and augmentative biological control strategies because they have no or low impact on natural enemies and biodiversity and are considered safe in terms of human health [5,6]. EF are efficient biological control agents of a wide range of mites, but none have been identified for the control of $P$. gracilis populations.

The objective of this study was to assess the pathogenicity of three strains of EF, two of Beauveria bassiana (Balsamo-Crivelli) Vuillemin and one of Metarhizium anisopliae (Metchnikoff) Sorokin, on the eriophyoid mite, P. gracilis, under laboratory conditions. The identification of virulent pathogenic fungal strains is of great interest for the development of a potential biological control agent for this phytophagous mite [7]. 


\section{Materials and Methods}

Fungal strains were provided by the Plant and Pathogens Group of the Research Institute, Earth, Nature, Environment of Hepia (Geneva, Switzerland). Entomopathogenic fungi (Beauveria bassiana (strains BB 1.1 and BB 11.6), Metarhizium anisopliae (strain MA 10.1) were isolated from soil samples collected across Switzerland using the "Galleria bait" method [8] and grown on solid medium of potato glucose agar (PGA: potato $4 \mathrm{~g} / \mathrm{L}$, glucose $20 \mathrm{~g} / \mathrm{L}$, agar $15 \mathrm{~g} / \mathrm{L}, \mathrm{pH}$ 5.4). Subcultures were grown on PGA at $24^{\circ} \mathrm{C}$ in the dark for 14 days. Spores were harvested by scraping subcultures and suspended in $10 \mathrm{~mL}$ of sterile water $[9,10]$. Suspensions were then filtered through a sterile aluminum sieve of $100 \mu \mathrm{m}$ pore size, into a sterile plastic tube. Fungal spore suspensions were mixed for $5 \mathrm{~min}$, and the spore concentration was determined using a counting chamber (Kova ${ }^{\circledR}$ Glasstic $^{\circledR}$ slide 10, Hycor Biomedical Inc., Garden Grove, CA, USA) [9]. Spore suspensions were then adjusted to a concentration of $1 \times 10^{7}$ spores per $\mathrm{mL}$ [10]. For each bioassay, spore suspensions were prepared and used on the same day [11]. Spores were left in solution at least two hours before use to allow spore rehydration and swelling. Spore viability was assessed according to [9] $24 \mathrm{~h}$ after inoculation. Briefly, spore suspensions were titrated to $1 \times 10^{4}$ spores $/ \mathrm{mL}$ and plated on Sabouraud dextrose agar (SDA). Spores were observed under a microscope and considered germinated when the germ tube was at least as long as the diameter of the spore [12,13].

Phyllocoptes gracilis were collected from a highly infested organic plantation of raspberry cv. "Tulameen" in Eastern Switzerland. The mite species was identified through microscopic study using the simplified key to the family of Eriophyoidea (Linder 2016, unpublished). Mites were reared on small and healthy raspberry plants (cv. "Tulameen") in a climatic chamber (Conviron Seed germinator G1000, Controlled Environments Ltd., Winnipeg, MB, Canada) at $25 \pm 3{ }^{\circ} \mathrm{C}$ with a relative humidity of $72 \pm 10 \%$ and a photoperiod of $16 \mathrm{~h}: 8 \mathrm{~h}$ (light/dark). The infestation of new leaves was done according to [14].

According to observations made by [15], eriophyoid mites are sensitive to physical manipulation so the transfer of mites with a microneedle usually results in high mortality. Therefore, our bioassay method was adapted to the small size of eriophyoid mites by pre-counting the mites on infested leaves before application of the treatment.

Leaf discs of $3 \mathrm{~cm}$ in diameter were cut from infested leaves of similar maturity and then cut in half [16]. Eriophyoid mites were counted at 70× magnification and dead individuals were removed from the infested leaves. Each individual was counted because it is not possible to differentiate an adult from an immature or a male from a female at $70 \times$ magnification. Then, leaf discs were immersed for $5 \mathrm{~s}$ in the spore suspension according to [17]. The control was treated with a solution of sterile water as in [16,18].

After treatment, leaves were placed with the abaxial surface upwards on filter paper saturated with sterile water in plastic Petri dishes (55 $\mathrm{mm}$ diameter, $17 \mathrm{~mm}$ depth). Petri dishes were placed in a climatic chamber (as above) at $25 \pm 3{ }^{\circ} \mathrm{C}$ with a relative humidity of $72 \pm 10 \%$ and a photoperiod of $16 \mathrm{~h}: 8 \mathrm{~h}$ (light/dark). Each treatment was replicated 10 times.

Mortality was recorded three, five and seven days after the application of the spore suspension [10]. The anterior ends of the mites were gently nudged with a single hair paintbrush to provoke movement and the mites were considered dead if they did not react [17].

Statistical analyses were performed with R software (version 4.0.4). In order to analyze the effects of the two categorical predictors (treatment and day after inoculation) on mite survival 3, 5 and 7 days after inoculation, we fitted generalized linear models (GLMs) to our data with a binomial error distribution and a logit link function [19]. We used the emmeans function [20] for comparing the group means of significant variables $(p<0.05)$.

\section{Results}

At all three measurement points (days after inoculation), the mortality was highest for BB_1.1 (36\%; 66\%; 80\%) and MA_10.1 (31\%; 60\%; 76\%) and lowest for the control $(10 \%$; 
$28 \% ; 44 \%$ ) (Figure 1). Inoculation with BB_11.6 triggered a significantly lower mortality than with BB_1.1 and MA_10.1 and a significantly higher mortality than the control at all three time points $(24 \% ; 51 \% ; 69 \%)$. The mortality increased with days after inoculation. 


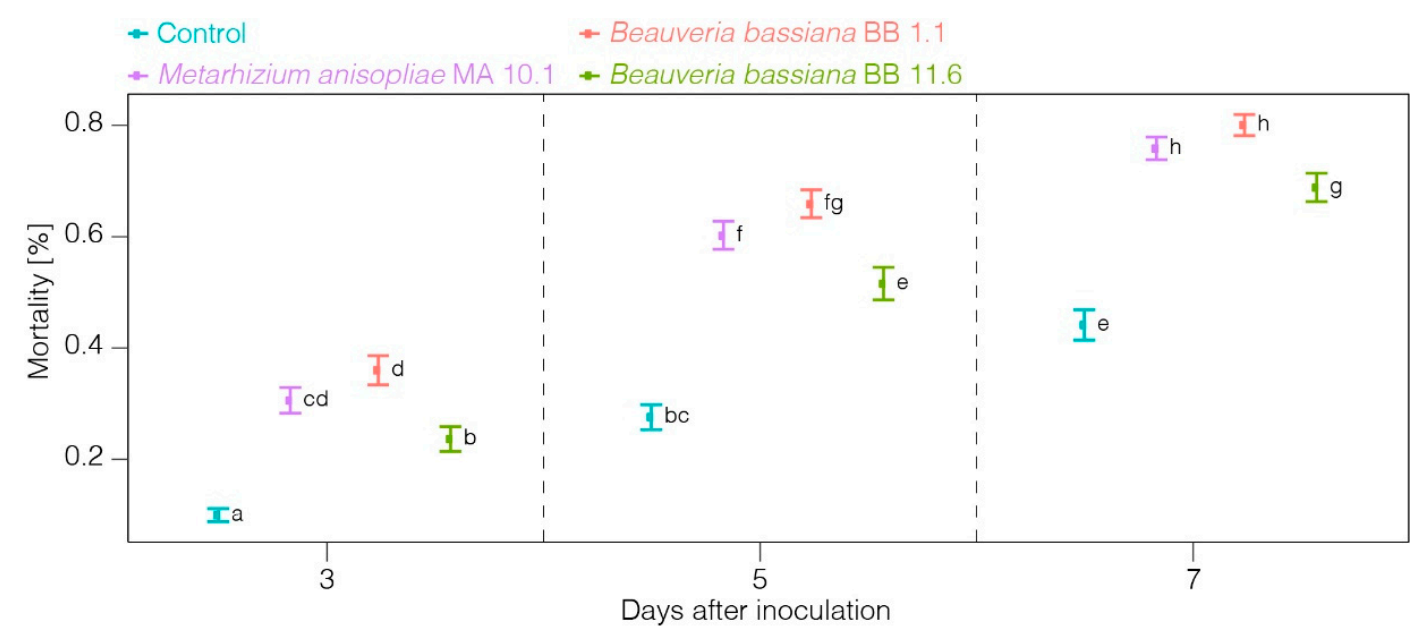

Figure 1. Mortality and asymp. confidence intervals (0.95) of $P$. gracilis, three, five and seven days after treatment application.

\section{Discussion}

Naturally occurring EF are important regulators of arthropod populations [5] and thus good potential biological control agents for phytophagous mites and insects [6,21]. Several strains of EF are already used in classical and augmentative biological control as well as in conservation strategies [6] and have proved successful against a range of mites, such as Hirsutella thompsonii Fisher [22]. In some cases, the use of EF in rotation with chemical miticides is recommended to improve the efficacy of crop protection strategies [6]. The use of EF is considered safe to humans and appears to pose minimal risk to non-target organisms as there are few reports of infection of predatory mites by EF [6].

Eriophyoid mites represent good hosts for EF because they are soft-bodied organisms without hard cuticular barriers (soft cuticle) [22]. In addition, eriophyoid mites often live in humid and dark microhabitats with microclimatic conditions favorable for fungal development [23]. Although no previous study on the pathogenicity of EF to the eriophyoid mite $P$. gracilis has been found, similar experiments on other eriophyoid mites have been performed previously. Alves et al. tested the pathogenicity of B. bassiana to the eriophyoid mite, Phyllocoptruta oleivora, at different spore concentrations [24]. The mortality of $P$. oleivora was observed two days after treatment application. At a concentration of $1 \times 10^{7}$ spores $/ \mathrm{mL}$, the study reached similar results to ours with a mortality of $64.1 \% \pm 11.9 \%$ after 5 days. The pathogenicity of the different strains was assessed. Different B. bassiana strains applied to the eriophyoid coconut mite, Aceria guerreronis, caused mortality ranging between $72.9 \%$ and $87.0 \%$ five days after treatment application at a concentration of $1 \times 10^{8}$ spores $/ \mathrm{mL}$ [25].

In this study, the mortality of $P$. gracilis in the control group was relatively high in comparison with the mortality reached in the control of other eriophyoid mite species under similar experimental conditions. Indeed, the mortality of P. oleivora in the control reached $6 \pm 1.15 \%$ while the mortality of $A$. guerreronis amounted to $2.33 \%$ five days after treatment application $[24,25]$. This relatively high mortality in the control may indicate that the conditions of the climatic chamber might not have been optimal for $P$. gracilis development. Further experiments are therefore needed to optimize the climatic conditions for rearing $P$. gracilis.

Follow-up studies should repeat this experiment on different populations of $P$. gracilis to confirm the pathogenicity of tested fungal strains and compare their virulence. A comparison of virulence with commercial formulations of B. bassiana and M. anisopliae would be of great importance. It would also be necessary to test different concentrations of spores to find the most economically viable strain, as performed in [24], where the lowest concentrations showed the lowest mortality scores but were the most cost-effective, enabling more applications in citrus orchards and therefore provided a better control of 
P. oleivora. Finally, it is necessary to investigate the effects of the selected fungal strains on beneficial organisms found in raspberry crops in Switzerland.

Author Contributions: Conceptualization, C.M. and L.N.; methodology, C.M. and L.N.; data analysis, C.M. and A.B.; writing—original draft preparation, C.M.; writing—review and editing, C.M., L.N., A.B. and B.C. All authors have read and agreed to the published version of the manuscript.

Funding: This research received no external funding.

Data Availability Statement: Data available on request.

Acknowledgments: The authors are grateful to François Lefort from the Plant and Pathogens Group of the Institute Earth Nature Environment of Hepia (Geneva, Switzerland) for providing the fungal strains and laboratory support.

Conflicts of Interest: The authors declare no conflict of interest.

\section{References}

1. Baroffio, C. Culture des Framboises-Maladies et ravageurs. In Guide des Petits Fruits; Ançay, A., Baroffio, C., Michel, V., Häseli, A., Kopp, M., Eds.; Editions Fruit Union Suisse: Zug, Switzerland, 2017; p. 73.

2. Gordon, S.C.; Taylor, C.E. Some aspects of the biology of the raspberry leaf and bud mite (Phyllocoptes (Eriophyes) Gracilis Nal.) Eriophyidae in Scotland. J. Hortic. Sci. 1976, 51, 501-508. [CrossRef]

3. Gordon, S.C.; Woodford, J.A.T.; Birch, A.N.E. Arthropod pests of Rubus in Europe: Pest status, current and future control strategies. J. Hortic. Sci. 1997, 72, 831-862. [CrossRef]

4. Wekesa, V.W.; Hountondji, F.C.C.; Dara, S.K. Mite Pathogens and Their Use in Biological Control. Prospects for Biological Control of Plant Feeding Mites and Other Harmful Organisms; Springer International Publishing: New York, NY, USA, 2015 ; pp. $309-328$.

5. Lacey, L.A.; Frutos, R.; Kaya, H.K.; Vail, P. Insect pathogens as biological control agents: Do they have a future? Biol. Control 2001, 21, 230-248. [CrossRef]

6. Shah, P.A.; Pell, J.K. Entomopathogenic fungi as biological control agents. Appl. Microbiol. Biotechnol. 2003, 61, 413-423. [CrossRef] [PubMed]

7. Shapiro-Ilan, D.I.; Fuxa, J.R.; Lacey, L.A.; Onstad, D.W.; Kaya, H.K. Definitions of pathogenicity and virulence in invertebrate pathology. J. Invertebr. Pathol. 2005, 88, 1-7. [CrossRef] [PubMed]

8. Zimmermann, G. The "Galleria bait method" for detection of entomopathogenic fungi in soil. J. Appl. Entomol. 1986, 102, 213-215. [CrossRef]

9. Ullah, M.S.; Lim, U.T. Laboratory bioassay of Beauveria bassiana against Tetranychus urticae (Acari: Tetranychidae) on leaf discs and potted bean plants. Exp. Appl. Acarol. 2015, 65, 307-318. [CrossRef] [PubMed]

10. Lefort, F.; Fleury, D.; Fleury, I.; Coutant, C.; Kuske, S.; Kehrli, P.; Maignet, P. Pathogenicity of entomopathogenic fungi to the green peach aphid Myzus persicae Sulzer (Aphididae) and the European tarnished bug Lygus rugulipennis Poppius (Miridae). Egypt. J. Biol. Pest Control 2014, 24, 379-386.

11. Mishra, S.; Kumar, P.; Malik, A. Effect of temperature and humidity on pathogenicity of native Beauveria bassiana isolate against Musca domestica L. J. Parasit. Dis. 2015, 39, 697-704. [CrossRef] [PubMed]

12. Luz, C.; Fargues, J. Temperature and moisture requirements for conidial germination of an isolate of Beauveria bassiana, pathogenic to Rhodnius prolixus. Mycopathologia 1997, 138, 117-125. [CrossRef] [PubMed]

13. Arthurs, S.; Thomas, M.B. Effects of temperature and relative humidity on sporulation of Metarhizium anisopliae var. acridum in mycosed cadavers of Schistocerca gregaria. J. Invertebr. Pathol. 2001, 78, 59-65. [CrossRef] [PubMed]

14. Reed, D.K.; Burditt, D.K.; Crittenden, C.R. Laboratory methods for rearing rust mites (Phyllocoptruta oleivora and Aculus pelekassi) on Citrus. J. Econ. Entomol. 1964, 57, 130-133. [CrossRef]

15. Villalon, B.; Dean, H.A. Hirsutella thompsonii a fungal parasite of the citrus rust mite Phyllocoptruta oleivora in the Rio Grande Valley of Texas. Entomophaga 1974, 19, 431-436. [CrossRef]

16. Mikunthan, G.; Manjunatha, M. Fusarium species: Acaropathogenic fungi as potential control agents against coconut mite, Aceria guerreronis. In Trends in Acarology; Springer: Dordrecht, Germany, 2010; pp. 445-447.

17. Omoto, C.; Dennehy, T.J.; McCoy, C.W.; Crane, S.E.; Long, J.W. Detection and characterization of the interpopulation variation of citrus rust mite (Acari: Eriophyidae) resistance to dicofol in Florida citrus. J. Econ. Entomol. 1994, 87, 566-572. [CrossRef]

18. Aghajanzad, S.; Mallik, B.; Chandrashekar, S.C. Bioefficacy of six isolates of Hirsutella thompsonii Fisher against citrus rust mite, Phyllocoptruta oleivora Ashmead (Acari: Eriophyidae) and two spotted spider mite, Tetranychus urticae Koch (Acari: Tetranychidea). Pak. J. Biol. Sci. 2006, 9, 871-875. [CrossRef]

19. Goodrich, B.; Gabry, J.; Ali, I.; Brilleman, S. Rstanarm: Bayesian Applied Regression Modeling via Stan. R Package Version 2.21.1. 2020. Available online: https:/ / mc-stan.org/rstanarm (accessed on 13 March 2021).

20. Length, R.V. Emmeans: Estimated Marginal Means, aka Least-Squares Means. R Package Version 1.5.4. 2021. Available online: https:/ /CRAN.R-project.org/package=emmeans (accessed on 13 March 2021). 
21. Chandler, D. Chapter 5-Basic and applied research on entomopathogenic fungi. In Microbial Control of Insect and Mite Pests; Lacey, L.A., Ed.; Academic Press: Cambridge, MA, USA, 2017; pp. 69-89.

22. Lindquist, E.E.; Bruin, J.; Sabelis, M.W. Eriophyoid Mites: Their Biology, Natural Enemies and Control; Elsevier: Amsterdam, The Netherlands, 1996.

23. Chandler, D.; Davidson, G.; Pell, J.K.; Ball, B.V.; Shaw, K.; Sunderland, K.D. Fungal biocontrol of Acari. Biocontrol Sci. Technol. 2000, 10, 357-384. [CrossRef]

24. Alves, S.B.; Tamai, M.A.; Rossi, L.S.; Castiglioni, E. Beauveria bassiana pathogenicity to the citrus rust mite Phyllocoptruta oleivora. Exp. Appl. Acarol. 2005, 37, 117-122. [CrossRef] [PubMed]

25. Kalmath, B.; Mallik, B.; Onkarappa, S.; Girish, R.; Srinivasa, N. Isolation, genetic diversity and identification of a virulent pathogen of eriophyid mite, Aceria guerreronis (Acari: Eriophyidae) by DNA marker in Karnataka, India. Afr. J. Biotechnol. 2012, 11, 16790-16799. 